\title{
The Level of Community Participation in Supporting Community- Based Tourism on Mount Merapi Slope
}

\author{
Muhamad Muhamad $^{1 *}$, Syamsul Maarif ${ }^{2}$, Slamet Widiyanto ${ }^{3}$ \\ ${ }^{1}$ Master Program of Tourism Studies Postgraduate School Universitas Gadjah Mada, Yogyakarta, Indonesia \\ ${ }^{2}$ The Center for Religious and Cross-cultural Studies (CRCS) Postgraduate, Universitas Gadjah Mada, \\ Yogyakarta, Indonesia \\ ${ }^{2}$ Department of Tropical Biology, Faculty of Biology, Universitas Gadjah Mada, Yogyakarta, Indonesia
}

Submitted: December 28 $8^{\text {th }} 2020$; Revised: May 09 ${ }^{\text {th }} 2021$; Accepted: May $18^{\text {th }} 2021$

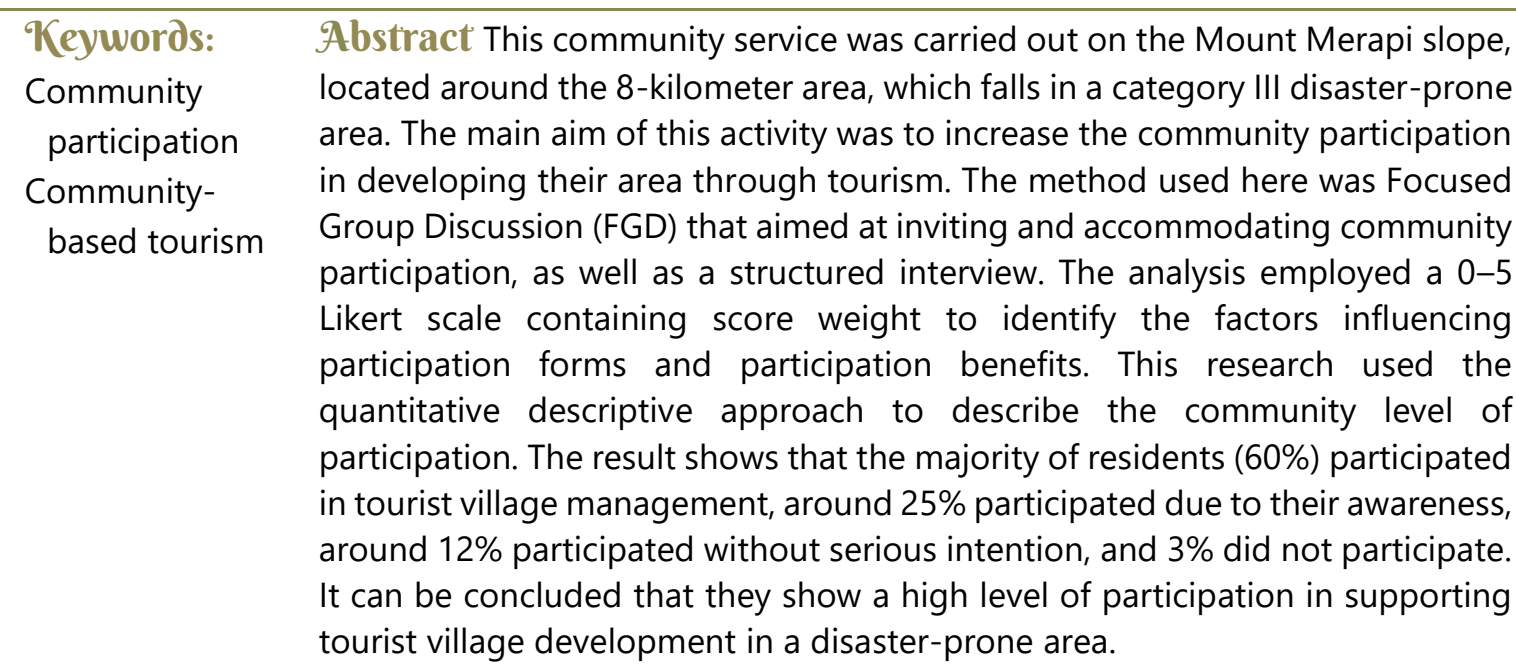

\section{INTRODUCTION}

Community-based tourism is crucial and fundamental to empower the rural community. This research is expected to be an accurate basis for developing programs that fulfill the needs of selected villages. This development is the most suitable and strategic decision, both for the institution's and nation's interest for national development. It is expected to bring the positive effect of human resources empowerment in rural areas through education and training. Furthermore, villages are the living areas of most Indonesian people. As many as $82 \%$ of Indonesian people live in rural areas (The Ministry of National Development Planning, 2011); thus, empowering villages means empowering the nation.

The village is the core element in sustaining the nation's unity and advancement; thus, neglecting their community can hinder national development. They should be empowered according to their condition and potential by designing a development program that suits the related institutions and community members themselves. Several things need to be considered here: (1) village organization should involve all elements and institutions, from the lowest to the highest, such as family, neighborhood, village, subdistrict, and regency; (2) it should be conducted independently and developed continuously to fit the demands and needs of the community; (3) the program should be designed through the following steps: planning, implementation, monitoring, evaluation, and follow-ups; (4) cooperation with stakeholders should be developed; and (5) the development should be aimed at making the village a unit that can strengthen the social structure of the residents.

ISSN 2460-9447 (print), ISSN 2541-5883 (online)

${ }^{*}$ Corresponding author: Muhamad

Master Program of Tourism Studies Postgraduate School Universitas Gadjah Mada, Kompleks Bulaksumur J-3, Yogyakarta, Sagan, Caturtunggal, Depok Sub-District, Sleman Regency, Special Region of Yogyakarta 55281, Indonesia

Email:drmuhammad@ugm.ac.id 
Kalibening Village is located in the southern area of Dukun Subdistrict, Magelang Regency. Tegalrandu Village, Srumbung Subdistrict, lies to the south of its border, and Wates Village lies to its west. In the north, it borders Sumber Village, and in the east, it is directly adjacent to Ngargomulyo Village. It has a population of $\pm 2,895$ people, consisting of 1,304 men and 1,591 women, or 897 families, 9 community associations, and 35 neighborhood associations. Most of the population work as farm workers. Out of the 38.268 ha village area, only $68.3 \%$ (427 ha) is arable land. The other $31.2 \%$ (242.32ha) is dry rain-fed land, while the rest is planted with tree crops such as Albizia chinensis, teak, mahogany, mango, banana, and kapok trees which only produces barely enough for daily needs.

Kalibening Village lies 6.8 kilometers to the west of the top of Mount Merapi. It falls under ring 1 or disaster-prone area 3 of the mountain and is situated 650 meters above sea level with an average temperature of $25-27^{\circ} \mathrm{C}$. It is geographically located in a fertile area, but the recently increasing illegal sand mining on Merapi slopes has been damaging its forest area. The activity eventually reduces the once-abundant water supply for agricultural works and daily needs. This condition is aggravated by the damaged dams and irrigation channels due to flooding during the rainy season. It is further worsened by the damage to other infrastructures, such as the main and the village roads.

Although the village is vulnerable to Merapi eruptions, it has several attractions with great potential as tourism sites, especially its landscape beauty and local culture. Village development is an annual program and activity that aims at increasing the rural community's ability to adapt and mitigate environmental damage, as well as mobilizing the community, government, and business sector for sustainable improvement and preservation. Some important aspects to note here are: (a) Kalibening is highly vulnerable to disasters, especially Merapi eruption because it lies approximately $6 \mathrm{~km}$ from the top of the volcano, (b) this village is resilient in responding to Merapi eruption and it has two sister villages, namely Tanjung and Ngadikarto Villages in Muntilan Subdistrict. Cooperation between the three villages was established in 2011 as marked by the signing of Memo of Understanding (MoU) by their heads.

The position and contribution of pilot disasterresilient villages are the most important response in disaster-prone areas, and the community has sustainably implemented it. Thus, they can proceed on developing their potential as sustainable tourism sites safely and comfortably. The position and contribution of the pilot village are as follows: a) the position and role of tourism activity strategies applied in the selected village is a part of integrated regional development to empower the community, b) regional development through tourism activities in village is following the community initiative and as a response to Law No. 16 of 2014 regarding village laws.

This development program is essential to position the tourism sector, which contains strategic characteristics and values, to build sustainable tourism. This attempt should be considered due to several reasons, including a) the position and role of tourism strategies as the agents of regional development and rural community empowerment, b) local resourcebased industry, a tourism industry characterized by high utilization of local resources and labor intensity that is effective in absorbing workforce and opening up business opportunities in the area, c) the immense interrelation between cross-sector and cross-scale businesses, thus the tourism sector has an immense ability to generate multiple economic impacts for the community.

Based on the strategic values mentioned, it can be seen that the position and contribution of tourism as an effective method for regional development and improvement are increasingly clear and strong. According to Barry and Barham (2012), the development of the tourism sector as disaster management has several functions and objectives, one of which is its position as a strategic sector.

Community empowerment is an effort to create or increase the community capacity, both individually and in groups, to solve problems related to life quality improvement, independence, and wellbeing. This empowerment requires a huge contribution from the local governments and other parties to provide opportunities and ensure the sustainability of the outcomes. Community empowerment is highly important considering that the community is one of the development stakeholders, apart from the government and the private sector. Thus, tourism development can be implemented at the community level for better empowerment

The main issue encountered by the target community here is their inability to handle the aftermath of the Merapi eruption. Their social, economic, and cultural resilience in the disaster-prone area still requires considerable attention that should be manifested into efforts for community empowerment and/or strengthening institutional capacity. Those efforts can help accelerate their recovery post Merapi eruption, especially the social and economic aspects that are important for improving their wellbeing and independence. This study is the academics' concern, responsibility, and obligation to assist the government in mitigating natural disasters and accelerating the recovery process.

According to Ritchie (2000), disaster management is not only the duty and responsibility of 
the government but also the wider community, which should be implemented through anticipative measures employing community-based power and realized through community empowerment and participation based on the local resource capability (community disaster management). Based on the Law of the Head of Indonesian National Board for Disaster Management (Kepala Badan Nasional Penanggulangan Bencana or BNPB) No. 4 of 2008 regarding the Guidelines for Disaster Management Planning in Chapter IV their characteristics of development. Therefore, the approach used in the empowerment program is Community-Based Strategic Planning.

Developing the assisted community through tourism can be carried out openly, making it possible for them to exercise their rights, such as providing information, data, responses, suggestions, and other inputs for the program. Thus, the plan will be more aspirational and can accommodate the various interests of various society members. This community-based

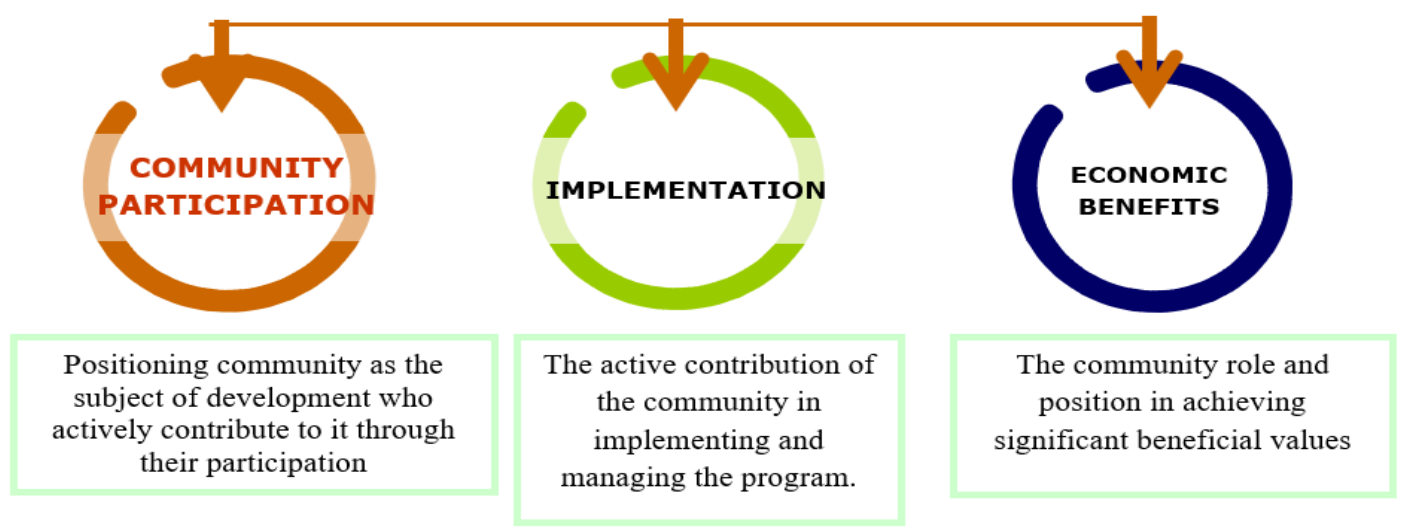

Figure 1. Chart illustrating the community-based approach

Allocation and Role of Disaster Management Members that explain the role and potential of community members, one of which is university or research institutions, it is mentioned that effective and efficient disaster management requires proper application of science and technology. Hence, idea contribution from the experts in both institutions is considerably needed. For this reason, this research aimed to implement a timely increase in the community participation in tourism development in the disasterprone area after the eruption of Mount Merapi.

According to Bridges (1974), one of the strategies to tackle poverty in rural communities and manage disaster-prone areas is by empowering the community members themselves. This concept can define and fulfill their needs. The inadequacy of skills they acquired has led to their inability to recognize what they need to improve life quality.

Active and high participation from the rural community in the empowerment process, such as in the development program carried out by Universitas Gadjah Mada (UGM) through Community Service Briefing and Guidance (P2KM), is significantly needed to support community independence. This program plays the role of the enabler, which aims at accelerating changes, the encourager, and the educator. With the help of this program, people will gradually develop independence. The residents, local institutions/associations, and non-governmental institutions are the factors that determine the development of their respective villages according to development is illustrated in Figure 1.

Figure 1 shows that rural community participation in building sustainable tourism management, particularly the village potential, can be seen in three aspects. First, we need community participation, which positions the community members as subjects who actively contribute to forming a shared learning community. Second, an implementation through the initiation of integrated programs and sustainable management. Third, the expectation that targeted values and benefits can improve community welfare Suansri (2003) explained that participatory tourist village development is expected to strengthen the community capacity and empower their socio-cultural sector, economic sector, and management of tourism resources based on cooperation and local wisdom. The existence of a tourist village can stimulate their creativity to explore, optimize, and preserve the existing cultural potentials.

In line with the previously mentioned study, research conducted by Muhamad and Prima (2016) in the tourist village of Pulesari, Donokerto Village, Turi Subdistrict, shows that tourism resources management should be based on the utilization of village potentials and cultural preservation, as well as landscape conservation and maintenance (Muhamad, 2009). Efforts to motivate community participation in tourism awareness can function as the actors of tourism development. The existence of institutions is important as a means of collective communication and interaction 
as well as a means of strengthening the socio-cultural ties to develop tourist villages sustainably.

The factors encouraging participation, according to Setyawan and Rahmi (2000) and Suansri (2003), can be categorized into five groups. These include the existence of community organizations that fulfill the peoples' needs, the benefits obtained, and the commitment or obligation to respond by applying enhanced knowledge. To attract the youths, an organization should address the needs and interests of the youth in a certain issue. Additionally, the group should be supported by an initiator who has a good reputation and is accepted to be a figure among them.

Some of the achieved benefits may bring a significant impact on society's development. On the other hand, threats can encourage people to avoid possible negative occurrences (Suansri, 2003). The anticipatory efforts they make are motivated by moral, social, economic, and religious factors. The commitment and responsibility to give responses should be done voluntarily, motivated by the values held in the society. The last condition that motivates participation is the acquired and enhanced knowledge. The information received by individuals can highly influence their actions. Adequate information received might bring a positive stimulus for the individuals.

According to Suansri (2003), dynamic community participation refers to the type of contribution made by participants in activity implementation. This participation can be categorized into five forms, namely participation of ideas, skills, manpower, properties, and money (Haeruman \& Eriyatno, 2002). Idea participation is the capability to induce skills to manage the existing potentials and resources. On the other hand, manpower participation, especially hard labor, is manual participation in tourism development activities.

\section{METHODS}

This research applied qualitative and quantitative approaches collectively, in which the data were combined and analyzed in terms of their similarities, differences, and combination (Creswell, 2009). The main approach is qualitative descriptive via in-depth interview. A quantitative approach using the Likert scale was carried out as a supporting data collection method.

The Likert scale measuring the community participation in the community-based tourism development can be analyzed to measure the attitude, opinion, and perception of community members regarding the social phenomenon. In this research, the Likert scale was used to measure the community attitude and perception regarding their participation level in supporting tourism in a disaster-prone area.

The data were analyzed using the scoring method to identify the factors determining participation forms and benefits (Arikunto, 2010). The qualitative descriptive approach is expected to give an overview of and summarize various socio-cultural phenomena in the community of tourist villages. These method and analysis were a form of participation from an intensive learning process to understand the rural condition, which was carried out repeatedly and quickly, as illustrated in the following figure:

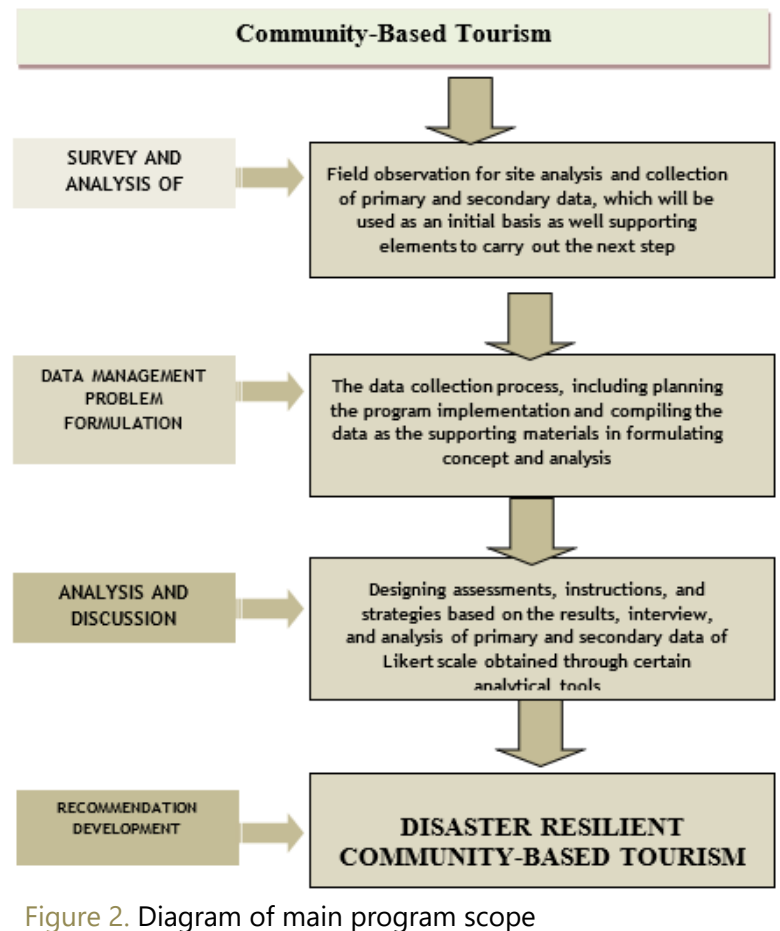

Figure 2 shows that community-based tourism can be developed through several steps, including identification and analysis of the rural environment condition, and then followed by problem formulation, analysis, discussion, and recommendation development. Creswell (2010) mentioned that surveys can be carried out in the preliminary step before the actual research. The planning of community-based tourism is the activities as well as the compilation of data and initial information to support the formulation of concept and analysis as well as the following activities (survey and field data compilation). The situation analysis was conducted during assisted village development program in 2016-2018, implemented through community service. A literature review is required to deeper understand the works of literature relevant to the selected topic (Arikunto, 2010). The technique applied here was a comprehensive study of various information sources, such as books, articles, magazines, the internet, etc. Investigation on the previously implemented models was also done.

\section{RESULT AND DISCUSSION}

The members of the targeted community have the right to manage and enjoy the results of the tourist village. They are one of the actors who manage the tourism sector, both individually and in the group. This 
management is handled by the community under the coordination of the Tourism Awareness Group. The members of the community have varied roles, such as being the board members of Tourism Awareness Group, the members of community groups, or as an individual part of the community. This contributive relation between the Tourism Awareness Group and the other management is the coordination and correction function. Meanwhile, the contribution of the three parties who manage the tourist villages is the operational function in managing tourist villages.

Table 1. The forms of participation in the duties and responsibilities of the tourism awareness group

\begin{tabular}{|c|c|}
\hline Position & Duties and Responsibilities \\
\hline Chairman I & $\begin{array}{l}\text { - Selected by and fully work for tourist } \\
\text { village, including coordinating, providing } \\
\text { information, promoting, and marketing. } \\
\text { - Dividing the duties fairly and being } \\
\text { responsible for the activities, as well as } \\
\text { reporting the activity results to all } \\
\text { community members. } \\
\text { - Carrying out other tasks related to the } \\
\text { tourist village. } \\
\text { - Formulating innovative development } \\
\text { concept. }\end{array}$ \\
\hline $\begin{array}{l}\text { Vice- } \\
\text { Chairman }\end{array}$ & $\begin{array}{l}\text { - Making an effort to create organization } \\
\text { management and periodical report. } \\
\text { - Deploy and determine organizational } \\
\text { policies according to the community's } \\
\text { aspirations and be accountable for their } \\
\text { implementation. } \\
\text { - Carrying out other tasks related to the } \\
\text { tourist village. }\end{array}$ \\
\hline $\begin{array}{l}\text { Secretaries I } \\
\text { and II }\end{array}$ & $\begin{array}{l}\text { - Compile, collect, and work on } \\
\text { creating orderly administration } \\
\text { and periodical reports. } \\
\text { - Completing secretarial duties, } \\
\text { welcoming tourists, creating a list } \\
\text { of staying tourists, leading village } \\
\text { tours, and providing information } \\
\text { to the tourists. } \\
\text { - Carrying out other tasks related to } \\
\text { the tourist village. }\end{array}$ \\
\hline $\begin{array}{l}\text { Treasures I } \\
\text { and II }\end{array}$ & $\begin{array}{l}\text { - Helping to purchase food and } \\
\text { beverages, as well as other } \\
\text { necessities for tourist arrival. } \\
\text { - Carrying out other tasks related to } \\
\text { the tourist village. }\end{array}$ \\
\hline Divisions & $\begin{array}{l}\text { - Carry out duties and obligations } \\
\text { with full responsibility and work } \\
\text { professionally and be accountable } \\
\text { for the implementation of duties. } \\
\text { - Carrying out other tasks related to } \\
\text { the tourist village. } \\
\text { - Forging partnerships and } \\
\text { cooperation }\end{array}$ \\
\hline
\end{tabular}

Table 1 explains that the board structure of Tourism Awareness Group has a strategic function and contribution in developing the village potentials for sustainable tourism. Thus, they can help in implementing community-based tourism development.

\subsection{Developing community-based tourism (CBT)} CBT development in tourist villages is a level one CBT where all members of the community are actively involved in the tourism management Suansri (2003). Further explanation by Ritchie (2000) about the purposes of tourism activities emphasizes more on enhancing the capacities and welfare of the local community who is the development actor. According to the results of the literature study, the developing CBT in tourist village requires several supporting resources, namely; 1) supporting facilities and accessibility, 2) advantage of geographical conditions, 3) availability of human resources, 4) community acceptance, 5) unique potential and product innovation, 6) financial support as the capital, 7) proper management and organization, 8) well-organized marketing system and market access, 9) leadership/inspiring figures, 10) strong partnership supported by the key factors determining the success of CBT, which is 11) involvement of local communities as the main actors. The following is an illustration of the importance of youth participation as the main actor in managing a community-based tourist village.

Broch (2013) and Potjana (2003) explained that community participation, as the key factor in determining the success of CBT, would motivate optimum management and utilization of the ten CBT capitals (Figure 3). Capitals in the forms of supporting facilities and accessibilities, human resources availability, and community acceptance have been discussed in the previous section. Other capitals and benefits of CBT success will be elaborated.

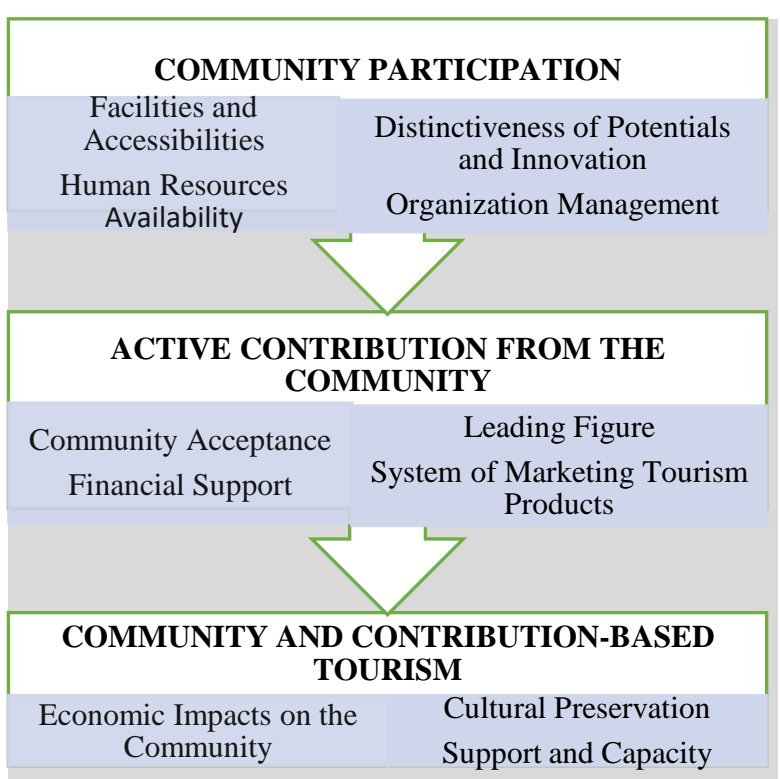

Figure 3. Community participation as the key success factor of CBT 


\subsection{Advantages of geographical conditions}

Geographical condition is a given natural capital for tourist villages. Strategic access and location can attract more tourists. These factors may benefit from the good geographical condition and rich natural resources, which provide the potential for tourist village management. The Merapi-Merbabu area is one of the 7 national tourism development areas in the Special Region of Yogyakarta and Central Java. This tourist village is located on the southern slope of Merapi Mountain, which also belongs to the tourism area according to the map of the Special Region of Yogyakarta and Central Java (Main Planning for Local Tourism Development or RIPPDA, 2018). Tourism categories and activities based on social, cultural, and environmental insight in tourist villages are important in the volcano slope area.

The development of products and tourist attractions in that area takes into account the uniqueness of local elements, both the physical and non-physical. The physical potentials include the distinctiveness of nature and environmental conditions, the diversity of natural resources, the processing of local products (culinary), and the produced handicrafts. On the other hand, non-physical potentials include customs and hospitality, local lifestyle, myths, socio-cultural conditions, and local history.

The community's socio-economic condition is one of the capitals for developing tourism destinations (Suansri, 2003). In agro-tourism packages, agricultural activities are managed by and for their farmers. Animal husbandry and fisheries are also managed by and for the breeders themselves. Therefore, the tourism management in the villages in Merapi slopes can directly and truly improve the local communities.

In addition to recreational and attraction functions, tourism packages also contain educational, tolerance, conservational, and preservational functions. The factors motivating youth participation in developing CBT were analyzed in five main categories. The categories were the existence of the appropriate organization, the benefits received, the existing threats, strong commitment, and more profound knowledge. The following is the analysis of the data obtained from 65 respondents.

Table 2. Motivational factors for community participation in Dewi Gendungan CBT

\begin{tabular}{clcc}
\hline No & \multicolumn{1}{c}{ Participation } & Score & Description \\
\hline 1 & $\begin{array}{l}\text { The development of a } \\
\text { tourist village is under } \\
\text { the aspirations and needs } \\
\text { of the community }\end{array}$ & 246 & High \\
2 & $\begin{array}{l}\text { Benefits are gained from } \\
\text { the tourist village }\end{array}$ & 250 & High \\
3 & $\begin{array}{l}\text { The development of } \\
\text { tourist village helps to }\end{array}$ & 220 & Medium
\end{tabular}

overcome the problems

of everyday life

4 There are responsibilities $260 \quad$ High and obligation to develop a tourist village

Table 2 shows that developing a tourist village that conforms to community members' aspirations and needs is crucial to optimally increase their motivations as well as the obtained benefits. Tourist villages are believed to be able to solve daily life problems and assign responsibilities and duties to the community to develop their area. This synchronization between the organization benefits obtained, and strong commitment is the most important factor in enhancing community participation. The residents often voluntarily engage in shaping and managing the village. Its existence can draw their interest to be involved, proud, and responsible for managing it.

The community's willingness and voluntary participation were induced by their sense of belonging, responsibility, and pride in the village. In addition, by being actively engaged with tourism management, the youth will be able to improve various skills and capabilities. Driven by those motivational factors, the following are the reasons for youth participation in the tourist village.

Table 3. Community's reasons for participating in the management of tourist village

\begin{tabular}{clcc}
\hline No & Forms of Participation & $\%$ & Description \\
\hline 1. & $\begin{array}{l}\text { Community's self- } \\
\text { awareness }\end{array}$ & $25 \%$ & Medium \\
2. & $\begin{array}{l}\text { Invited by other people } \\
\text { to participate }\end{array}$ & $60 \%$ & Medium \\
3. & Following other people & $12 \%$ & High \\
4. & No participation & $3 \%$ & High \\
5. & Pressured to participate & $0 \%$ & Medium \\
\hline
\end{tabular}

The data in Table 3 show that the majority of people living in tourist villages $(60 \%)$ participated in its management because they were invited by other residents. As many as $25 \%$ of respondents participated because of their awareness, $12 \%$ participated because they followed other people, and 3\% of the respondents did not participate. Meanwhile, none of the community members $(0 \%)$ participated because of pressure from other people. Such outcomes occurred because they have received explanations and invitations from various parties to be involved in the management. The village government and Tourism Awareness Groups hold an important role as the key actors in realizing participatory tourism village management.

\subsection{Community participation in developing a CBT}

People living in Kalibening Village participated in managing their tourism. Their participation can be analyzed into several forms of activities. The categorization used in this study is participation in the 
forms of money, property, manpower, skills, ideas, social contribution, decision making, and representation. Questionnaire results from 50 respondents show that the youth participation in developing CBT is as follows in Table 4.

In Table 4, the frequency score range of 275-327 indicates significantly high participation, 222-274 indicates high participation, 169-221 is medium participation, 116-168 is low participation, and 63-115 means very low participation. The highest participation was in physical activity participation (78.5\%) and skill contribution (76\%). On the other hand, money (53.2\%), materials $(54.5 \%)$, and idea (54\%) contributions only reached medium frequency.

Table 4. Forms of community participation in developing CBT

\begin{tabular}{|c|c|c|c|c|}
\hline No & $\begin{array}{l}\text { Participation } \\
\text { Forms }\end{array}$ & $\mathbf{F}$ & $\%$ & Description \\
\hline 1. & Money donation & 173 & 53.2 & Medium \\
\hline 2. & $\begin{array}{l}\text { Material donation } \\
\text { (working tools, } \\
\text { utensils, etc.) }\end{array}$ & 177 & 54.5 & Medium \\
\hline 3. & $\begin{array}{l}\text { Physical activity } \\
\text { participation }\end{array}$ & 247 & 76 & High \\
\hline 4. & $\begin{array}{l}\text { Skills contribution } \\
\text { (craftsmanship, } \\
\text { dance skill, being } \\
\text { guides, assisting } \\
\text { outbound, etc.) }\end{array}$ & 255 & 78.5 & High \\
\hline 5. & $\begin{array}{l}\text { Idea and opinion } \\
\text { contribution }\end{array}$ & 182 & 54 & Medium \\
\hline
\end{tabular}

The level of community participation can be measured using Arnstein's theory of participation (Arnstein, 1969) that divides participation level into three major categories or ladders, namely nonparticipation, tokenism, and citizen power. This research limits its analysis to only one initial participation. In this ladder, the community as the object of publication receives information and understands each management program of Dewi Gendungan. The level of the youth's understanding of the management program is elaborated in Table 5.

Table 5. The distribution of community participation frequency

\begin{tabular}{|c|c|c|c|c|}
\hline No & Participation & $\begin{array}{c}\text { Level of } \\
\text { Understanding }\end{array}$ & $\mathrm{F}$ & $\%$ \\
\hline \multirow{5}{*}{1} & \multirow{5}{*}{$\begin{array}{l}\text { Understand } \\
\text { the tourist } \\
\text { village } \\
\text { development } \\
\text { program }\end{array}$} & Completely understand & 10 & 15 \\
\hline & & Understand & 18 & 28 \\
\hline & & Somewhat understand & 18 & 28 \\
\hline & & Slightly understand & 12 & 18 \\
\hline & & Not at all & 7 & 11 \\
\hline \multicolumn{3}{|c|}{ Total } & 65 & 100 \\
\hline \multirow{3}{*}{2} & Participation & Level o & $\mathrm{F}$ & $\%$ \\
\hline & Joining the & Always ( $>5$ times) & 8 & 12 \\
\hline & training & Often $(<5$ times $)$ & 16 & 25 \\
\hline
\end{tabular}

\begin{tabular}{llcc} 
program in & Sometimes (3 times) & 12 & 18 \\
the tourist & Rarely (2 times) & 9 & 14 \\
village & Never & 20 & 31 \\
\hline & Total & 65 & 100 \\
\hline
\end{tabular}

Table 5 indicates that the majority of community members $(71 \%)$ understand the development program, with an understanding level ranging from moderate to complete. On the other hand, their participation in the training program reached only medium participation at $55 \%$. This condition was supported by their engagement in the management program, thus enabling easier access to information. Based on the analysis, it can be concluded that youth participation was at a medium level.

One of the community participation forms in the Kalibening Village development program is designing a program that corresponds to that of the village and local governments, which is relevant to the problems in the sector focused. The program planning is usually based on long-term sustainable thinking. The following are the sustainable activities carried out by rural communities in Kalibening Tourist Village, especially in Gendungan Hamlet as the targeted area of development program near Mount Merapi.

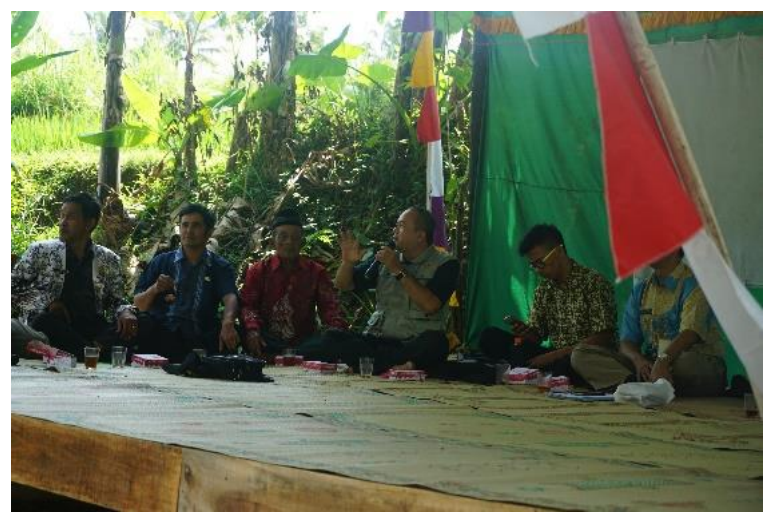

Figure 4. Focus group discussion between the local community, department of tourism, and universities to plan a participative tourism

Figure 4 shows the atmosphere of the focus group discussion (FGD) between the local community, local government, and university members to build communication and coordination. This cooperation should not be interpreted as only a means to sign the agreement, but more of strong social networking, both internally and externally. Internal partnership development is a collaborative network between the village government and the residents of Kalibening, both individually and in groups. On the other hand, the external partnership is a partnership built with various related parties or stakeholders. At this planning stage, the FGD, which allowed participatory planning activities, was very helpful to accommodate the residents' opinions. Those points are explained in Table 6. 
Table 6 shows that the proposed solutions agree with the paradigms and the participatory concepts of community-based tourism development. The participatory activities include assessments, training, and FGDs to obtain input and views from the community to build sustainable tourism. Thus, the community can create innovative ideas to determine the activity location and the possible development for the following year (Figure 5).

Table 6. Programs and solutions offered for development

\begin{tabular}{|c|c|c|c|}
\hline No & Activities/problems & Methods & Outcome Indicators \\
\hline 1 & $\begin{array}{l}\text { Inventory management of } \\
\text { tourism attractions and } \\
\text { objects (Kalibening Village) }\end{array}$ & $\begin{array}{l}\text { Assessment on appropriateness and } \\
\text { selling point, Focused Group } \\
\text { Discussion. }\end{array}$ & $\begin{array}{l}\text { Community participation in assessing and } \\
\text { joining training to enhance their capacity. }\end{array}$ \\
\hline 2 & Tourism packages & $\begin{array}{l}\text { Human resources training and } \\
\text { comparative studies to tourist } \\
\text { villages in Central Java and } \\
\text { Yogyakarta }\end{array}$ & $\begin{array}{l}\text { Community participation, exchanging } \\
\text { information with other tourism awareness } \\
\text { groups through a comparative study to improve } \\
\text { their knowledge and mindset. The readiness of } \\
\text { the community. }\end{array}$ \\
\hline 3 & $\begin{array}{l}\text { Community-based tourism } \\
\text { development master plan } \\
\text { document. }\end{array}$ & $\begin{array}{l}\text { Participatory framework, Focus } \\
\text { Group Discussion, and participatory } \\
\text { input in developing tourist village. }\end{array}$ & $\begin{array}{l}\text { Master plan document of participatory tourism } \\
\text { development in Kalibening }\end{array}$ \\
\hline
\end{tabular}

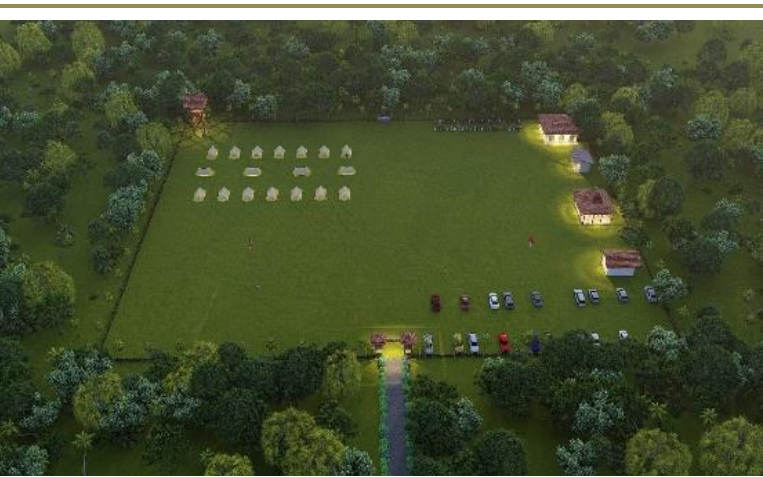

Figure 5. The campsite as a form of tourism development

\section{CONCLUSIONS}

The participation level of all community members in developing community-based tourism (CBT) was high. They were able to build an innovative thinking framework to determine the activity location and further possible development. The partnership between the stakeholders in the planning process is not only interpreted as a means to sign an agreement but more of a form of strong social networking, both internally and externally. Internal partnership development is a collaborative network between the village government and the community in Kalibening Village, both individually and in groups.

\section{ACKNOWLEDGEMENT}

The authors would like to thank the Directorate of Community Service through Assisted Village Development Scheme and Sub-Directorate of Community Service Between Semesters, Universitas Gadjah Mada, Yogyakarta, Regional Planning and Development Agency (Badan Perencana Pembangunan Daerah or Bappeda) and Tourism Department of Magelang Regency, and Kalibening Village government and hamlet tourism activists.for its support and facilities, community engagement partners, and all those who had helped the authors execute these activities.

\section{REFERENCES}

Arikunto, S. (2010). Prosedur Penelitian: Suatu Pendekatan Praktik (Edisi Revisi 2010), Jakarta: Rineka Cipta.

Azwar, S. (1995). Sikap Manusia Teori dan Pengukurannya, Yogyakata, Liberty.

Arnstein, S.R., (1969), A Ladder of Citizen Participation", Journal of the American Planning Association, Vol 35: 4, (1969) pp. 216 - 224.

Bappenas.(2011). Laporan Akhir Kajian Pembagunan Perdesaan Dalam Konteks Peningkatan Kesejahteraan Masyarakat. Jakarta: Direktorat Evaluasi Kinerja Pembangunan Sektoral, BAPPENAS.

Barry, N., Barham, J. (2012). Review of Existing Practices to Ensure Participation of DisasterAffected Communities in Humanitarian Aid

Berke, P., Beatley. (1997). T. After the Hurricane: Linking Recovery to Sustainable Development in the Caribbean; Johns Hopkins University Press: Baltimore, Maryland, USA,

Breugel, Liedewij van. (2013). Community-Based tourism: Local Participation and Perceived Impacts, Thesis: Faculty of Social SciencesRadboud University Nijmegen.

Bridges, William R.(1974). Citizen Participation in Community Development (internet), Ohio State University Face Sheet, http://ohioline.osu.edu/cd-fact/1700.html (accessed on 9 November 2015). 
Broch, Harald B. (2013). Social Resilience - Local Responses To Changes in Social and Natural Environments, Maritim Studies Springer Open Journal (internet), Juni, 12 (6) page. 1-17. http://www.maritimestudiesjournal.com> (accessed on 25 September 2015).

Baiquni, M. (2001). Participatory Rural Appraisal, Pendekatan dan Metode Partisipatif Dalam Pembangunan Masyarakat, National Training Session Cohort IX, Makalah disampaikan pada LEAD Leadership Environmental and Development, YPB Yayasan Pembangunan Berkelanjutan, Jakarta.

Creswell, J. W.(2010). Research Design: Pendekatan Kualitatif, Kuantitatif, dan Mixed. Yogjakarta: PT Pustaka Pelajar.

Haeruman, H.J.S., Eriyatno. (2002). Kemitraan dalam Pengembangan Ekonomi Lokal, Penerbit Yayasan Mitra Pembangunan Desa-Kota dan Busines Inovation Centre Indonesia, Jakarta.

Muhamad, Fandeli Chafid. (2009). Prinsip-prinsip Dasar Mengkonservasi Lanskap, Gadjah Mada University Press, Yogyakarata.

Muhamad. (2010). Kepariwisataan Berkelanjutan di Wilayah Yogyakarta Utara Setelah Erupsi 2010, (Interaksi Masyarakat di dalam Pengelolaan Lingkungan dan Kepariwisataan Alam), Disertasi Sekolah Pascasarjana Universitas Gadjah Mada Yogyakarta, Tidak diTerbitkan dan Tidak di Publikasikan, Yogyakarta.

Muhamad. (2014). Lanskap Kepariwisataan Alam di kawasan konservasi, Sekolah Pascasarjana UGM, Yogyakarata

Lodewijk, Maha Neni. (2013). Participatory Rural Appraisal, Pendekatan dan Metode Partisipatif Dalam Pembangunan Masyarakat, Bandung

Rencana Induk Pengembangan Pariwisata Daerah (RIPDA), 2015-2025, Pemerintah Kabupaten Magelang, 2018, Magelang.

Rencana Tata Ruang Wilayah (RTRW) 2015-2025, Pemerintah Kabupaten Magelang.

Ritchie, B.W. (2000). Crisis and Disaster Management for Tourism; Channel View Publications: Bristol, UK,

Setyawan. B., Rahmi, D.H., Mitchell, B. (2000).Pengelolaan Sumberdaya dan Lingkungan Hidup, Gadjah Mada University Press, Yogyakarta.

Suansri, P. (2003). Community-Based Tourism Handbook, Bangkok: Responsible Ecological Social Tour.

Wearing, S. dan Neil, J. (2009). Ecotourism: Impacts, Potentials, and Possibilities. Oxford: Elsevier. Weaver, D.B. (Ed.). 2001. The Encyclopedia of Ecotourism. Wallingford: CAB International. 